\title{
Reassessing Genres in Hugh MacLennan's “The Changed Functions of Fiction and Non-Fiction"
}

André Dodeman

\section{(2) OpenEdition \\ 1 Journals}

Electronic version

URL: https://journals.openedition.org/ces/8575

DOI: $10.4000 /$ ces.8575

ISSN: 2534-6695

Publisher

SEPC (Société d'études des pays du Commonwealth)

\section{Printed version}

Date of publication: 1 September 2009

Number of pages: 23-33

ISSN: 2270-0633

\section{Electronic reference}

André Dodeman, "Reassessing Genres in Hugh MacLennan's "The Changed Functions of Fiction and Non-Fiction"', Commonwealth Essays and Studies [Online], 32.1 | 2009, Online since 23 December 2021 connection on 17 February 2022. URL: http://journals.openedition.org/ces/8575; DOI: https://doi.org/ $10.4000 /$ ces. 8575

\section{(c) (i) $\odot$}

Commonwealth Essays and Studies is licensed under a Licence Creative Commons Attribution - Pas d'Utilisation Commerciale - Pas de Modification 4.0 International. 


\section{Reassessing Genres in Hugh MacLennan's “The Changed Functions of Fiction and Non-Fiction"}

This paper takes as a case in point an influential essay by Hugh MacLennan, a contemporary of cultural thinkers Marshall McLuhan and Northrop Frye, who also elaborated theories on national culture, so as to engage with the unstable, even porous boundaries between fiction and non-fiction, as well as the slippery nature of historical discourse caught in the interstices of positivist science and Aristotelian drama.

$\mathrm{H}$ ugh MacLennan marked twentieth century Canadian literature as a writer of politically committed historical fiction whose popularity was due largely to his essays warning against an economic, technological and cultural takeover on the part of the United States. He studied history at Dalhousie University in Halifax, Nova Scotia, before travelling to Europe and defending his thesis at Princeton in 1935. On his return from Europe, he acknowledged the fact that many Europeans and Americans knew little about Canada and he devoted the rest of his career to writing novels and essays which endeavoured to grasp Canadian specificity and identity. His first novel, Barometer Rising (1941), focuses on the notorious 1917 Halifax Explosion caused by the presence of British munitions ships in Halifax Harbour, which destroyed the city with its resulting tidal wave and conflagration. As Marta Dvorak points out, "the metaphorical, even apocalyptic overtones of the narrative invite a political reflection on, more specifically, the appropriateness of Canada's role in the war, and, more generally, on the nature and consequences of postcolonial relations" (186). His landmark novel, Two Solitudes (1945), on the tension of English-French relations in Quebec, "contributed a label to a cultural phenomenon" (Dvorak 186). The topics of his essays are varied: some of them are highly autobiographical and others deal with different aspects of Canadian culture such as hockey on ice and the twentieth century novel. MacLennan chose the form of the essay to question the role of the novel in society. In one of his essays, "The Future of the Novel as an Art Form", he dealt with the social and humanistic function of the novel and this paper will mainly focus on the essays which deal with the subject of fiction. The essay this paper will scrutinize, "The Changed Functions of Fiction and Non-Fiction", was written in 1967 and revealed the author's concerns about the academic influence over the respective definitions of history and fiction. The word "function" posits that the novel goes beyond its merely aesthetic contours. Even though non-fiction is an extremely heterogeneous category which can include academic writing, journalism, autobiography, biography, it shall be considered here as referring to the activity of history writing. The purpose of this paper is to analyse MacLennan's critique of the borders which differentiate fiction 
from non-fiction, for this distinction relies on the shifting boundary between each genre. However, MacLennan did not see these genres as absolutely separate and impervious to each other. He had a dynamic representation of these generic categories and wrote this essay in order to question their very existence, the stability of these categories. This essay shall analyse the rhetorical and polemical nature of his essay, the impact of which depends on the author's subjectivity and his desire to bond with the reader. To this purpose, he intentionally opposes two groups, the legitimate writers and readers who learn from literature on the one hand, and the pompous academics who seek to dictate their rules on the other. The first group grows stronger as the essay progresses and he pays tribute to figures such as Lytton Strachey and Barbara W. Tuchman, who both confirm his opinions on the boundaries between history and fiction. In this respect, MacLennan establishes a family tree from which academics are excluded. Finally, this paper shall deal with how these boundaries change in MacLennan's fiction. His novels offer the opportunity to see these shifting boundaries at work and the mix of essay and fiction conveys the idea that all texts are naturally hybrid and that ossified generic categories are what accounts for what he believed was the decline of the novel in the late twentieth century.

In Anatomy of Criticism, Northrop Frye defines the "essay" as a "trial or incomplete attempt", the purpose of which is to offer the "possibility of a synoptic view of the scope, theory, principles and techniques of literary criticism" (Frye 3). Many of the characteristics attributed to the essay appear in this quotation: the idea of trial, incompleteness, synopsis and its link with literature. What is perhaps missing in this aphorism, although it is used throughout Frye's essays, is the importance of the relation between subject and object. The essay form is often opposed to the supposedly objective treatise and entails the arguments and personal involvement of the writer.

The distinction between the treatise and the essay relies on the intersubjective relation between the writer and the reader, and in his polemical essay "The Changed Functions of Fiction and Non-Fiction", MacLennan plays with this subjective form not only to obtain the sympathy of the reader but also to assert his subjectivity against an entire system which he thinks has conveyed a distorted representation of the border between history and the novel. This system which he openly accuses is that of the academic field in general, and history professors in particular:

When I was young I wanted to be an historian. I had the idea that history was made by men and not by abstract forces or by laws of economics, and the field fascinated me. If I failed in it I think it was because in those days history was locked into the academies and the academics refused to admit that non-fiction prose can be an art. (MacLennan, $C F 238)^{1}$

1. Further page references provided in the main text. 
MacLennan gives a narrow definition of non-fiction in his essay, associating it with historical discourse and not with the rest of the categories which it can encompass, such as diaries or biographies. The subjective pronoun "I" clearly denotes the critique against the academic system, and the essay as genre provides the adequate form in order to do so. In choosing the form of the essay, MacLennan is able to assume his function as exotopic writer, for he was writing from within the institution as a literature professor at McGill University, and from the outside as he had already published five novels. In this case, the essay offers a space in which the writer can reconcile fiction and non-fiction and feel free to criticize and choose ironic modes said to be absent in his novels.

Unlike MacLennan the novelist, MacLennan the essayist was particularly rebellious against a system which dictated its own words to history students and explicitly expressed the desire to turn historical discourse into a positivistic science. The subject of MacLennan's doctoral thesis was the close study of the effects of the decline of the Roman Empire on its peripheral territories. He focused on the small Egyptian town of Oxyrhynchus, and in his essay he remembers the opening lines of his work: "Civilisation has always rested upon the patience of the poor and nowhere were the poor more patient than in Roman Egypt" (240). A few lines further, MacLennan offers the reader the correct translation of this sentence into academic language:

It would, however, be highly dangerous to infer from this that Egypt, at least until the fourth century A.D., presents a picture of relative stability in the prolonged economic crises which gripped the Empire from the death of Septimius Severus to the temporary stabilization of the currency on a gold standard by Diocletian roughly a century later. (241)

Through this essay, the writer criticizes the positivistic "literary highbrows", the centralizing tendency of scientific and objective language, the purpose of which is to claim "territorial sovereignty" over epistemological discourses. As scientific discourse centralizes, he finds no other solution but to "escape from the institution with an advanced degree" and devote his spare time to writing novels. In this respect, the essayist ceaselessly questions the border between both "territories" and invites the reader to do the same. The essay depends on an empathetic relationship with the reader. The essayist's aim is mainly argumentative and he needs to convince the reader that his attempts are justified. To do so, MacLennan starts his essay with autobiographical elements pertaining to his university years in the thirties. They are chosen in order to prove that such "literary highbrows" are disconnected from history writing, for the essay is also the precise form through which the writer can share his own truth. Such details are mainly related to his intellectual development as a university student and professor, and to his assumption that non-fiction writers "write better stories than the novelists" (238). The nature of the relationship between writer and reader greatly depends on the essay's heuristic content. 
Not only was MacLennan associated with history and the novel, but he was also known for his didacticism. This intimacy with the reader, shaped by the use of the subjective pronoun "I" and autobiography, aims at teaching the reader about crucial literary issues such as what he considers to be the late twentieth century decline of the novel. There are two distinct 'I's in his essay, one referring to the writer and the other to his past self, thereby stressing this dichotomy between past and present, youth and adulthood. The empathy which is sought in this essay relies on this wisdom and this experience acquired over the years, and the dominant didactic language conveys the idea that the author is all the more sympathetic as he has earned the privilege to understand the public better than anyone else:

The success of the story depends just as much upon the audience as it does upon the author, because the audience must be in a mood to be interested in it. That is why, these days, the non-fiction writer starts with advantages the novelist has lost. Today's public is deluged with facts and has been conditioned in school to accept nothing unless it has been proved. Never was there an audience so unwilling to suspend unbelief. (242)

The Canadian postmodern novel of the sixties questioned the relation between the signifier and the signified to such an extent that it weakened the authority of the author. In Canada, the form emerged from the country's struggle to define its identity against foreign centres such as the United States and Great Britain. Identity was to be sought on the borders between cultures which, according to Linda Hutcheon's The Canadian Postmodern, became "the postmodern space par excellence" (Hutcheon 4). A significant example is Leonard Cohen's Beautiful Losers (1966) which challenges centralizing conventions and decentralizes the authority of the narrator. In a similar fashion, the respective influences over history writing of Langlois and Seignobos at the turn of the century and of the Vienna Circle in the twenties and thirties tended to classify history among the social sciences which, in MacLennan's terms, meant loss of contact with the readership. This understanding of the audience is the necessary condition for the rhetorical and didactic effectiveness of the essay. MacLennan tries to decentralize academia by resorting to irony and asserting this exclusive pact between writer and reader. The brotherly and empathetic ethos, which is scrutinized by Pierre Glaudes in his introduction to L'Essai: Métamorphoses d'un genre, epitomizes the social role of the essayist who seeks to turn the reader into a friend and even to see another self shaped as the reader. But the essay's argumentative nature goes beyond his search for a double and sets out to find a family that needs to stand united against certain literary critics and historians who aim at stabilizing the borders between genres. In order to strengthen this empathetic relationship, MacLennan resorts to modesty to contrast with the condescending academies which look down on the public. Lukács wrote that the essay is the occasion for the writer to bind with the reader by assuming his humble condition, but such a task is nevertheless 
tinted with pride. More than wanting to teach people about the nature of the novel, MacLennan aims at gathering as many readers as he can around his ideas and assuming his position as the member of an intellectual family in which he is called to play an eminent part. Marie-Catherine Huet-Brichard writes that the essay today is a very protean genre in that the form lacks stability and precision. To legitimize the essay form, the writer searches for a family (34). In this respect, MacLennan attempts to assert his position, thereby reducing his historical role to a very limited, albeit important, one.

To support his arguments against the influence of positivism over history writing, MacLennan calls upon his extended knowledge of Ancient Greece and Rome. He mentions "Herodotus, Thucydides, Xenophon, Tacitus, Plutarcheven Clarendon and Gibbon" (239) so as to assert their historical precedence and the importance the Western canon. Their texts have blended plot and history, and the Ancients taught that like any individual existence, historical events had dramatic qualities with original situations, climactic moments and outcomes. In The Histories, Herodotus describes the Western world as he discovers it and does not refrain from including axiological discourses. Likewise, Thucydides was involved in the Peloponnesian War before writing its history with the demise of Greek democracy as a tragic outcome. According to these ancient writers, history is just as dramatic as fiction, and this conception of the genre had an important influence over the Aristotelian definition of tragic drama. In his Poetics, tragedy is the imitation of a noble action and aims at catharsis which consists in purging emotions. MacLennan inherited this conception of the hero in history and fiction. Reassessing genres means scrutinizing the borders that separate them from one another. The following lines from his essay categorize tragic drama as the "most intense" of all literary forms:

Of all literary forms, the most intense and important is tragic drama. It is created by the interaction of characters inextricably involved with the same situation, generally one which they cannot understand. [...] A tragic drama is a time-bomb. Once the fuse is ignited it cannot pause, it cannot retract, it cannot explain anything logically to itself. It simply burns with increasing heat to the moment of its inevitable detonation. It is a picture of life driven out of control by the very forces which are at the root of its genius and vitality. (243)

In this respect, a historical text can resort to fiction, the structures of which are influenced by Aristotelian drama. Plutarch's Parallel Lives illustrates this blurred border between genres as the writer was never reluctant to invent dialogues to give life to such historical characters as Alexander, Caesar or Cleopatra. Their stories are all conditioned by tragedy and the heroes' actions are governed by something superior to them. Their origins are often mysterious, their actions outstanding and their deaths particularly dramatic. For MacLennan, history should be written in the same non-positivistic fashion.

The essayist then establishes a link between these ancient writers and twentieth century literature, and it is first to be found in Lytton Strachey's Eminent 
Victorians. Here again, MacLennan's essay is shaped by the quest for continuity and for lineage. The essay becomes a tribute to contemporary writers, and he quotes directly from their various forewords. Strachey's preface to his biography openly asserts the intricate relation between historical narrative and art: "The history of the Victorian Age will never be written: we know too much about it. For ignorance is the first requisite of the historian-ignorance, which simplifies and clarifies, which selects and omits, with a placid perfection unattainable by the highest art" (Strachey 6). The "placid perfection" Strachey mentions is the result of thorough research, but also of the tradition set by ancient biographers such as Plutarch. History is being told by taking characters who transcend historical reality insofar as their features and actions overshadow the writing of the story. It is not the historical fact that is important, but how a character deals with a situation at a particular time. According to Bakhtin, the human characters are developed in biographical essays at the expense of historical reality:

Historical reality itself, in which disclosure of character takes place, serves merely as a means for the disclosure, it provides in words and deeds a vehicle for those manifestations of character: but historical reality is deprived of any determining influence on character as such, it does not shape or create it, it merely manifests it. Historical reality is an arena for the disclosing and unfolding of human characters—nothing more. (141)

The characters tend to dominate history and time in the biography. Strachey's essays concern four eminent historical figures: Cardinal Manning, Florence Nightingale, Dr. Arnold and General Gordon. The narratives of each life rely on a precise selection of fragments which supports or refracts the primary representation of the historian. The gaps between the fragments are indeed the appropriate place for fiction to seep into historical narrative and help the reader form a global representation of the character. Instead of orienting the reader's attention towards a historicist conception of history, with its causes and effects, the emphasis is lain on individual human beings and their decisions. Not only does this provide a more recognizable representation of history to the reader, but it is also meant to entertain. MacLennan pays yet another tribute to a modern historian: Barbara W. Tuchman, the author of The Proud Tower (1966) and The Guns of August (originally published as August 1914 in 1962). The Proud Tower displays this interconnection between historical discourse and fiction. The book portrays the history of Western civilisation from 1890 to 1914 and all of the events analysed progressively evolve toward the apocalyptic world war. It mainly deals with the society and politics of the chosen period and is symmetrically structured. The first chapter, "The Patricians", which studies European aristocracy and its power over the working classes, and the final chapter, "The Death of Jaurès", are linked by cause and effect. The final chapter represents the end of an era of pride, and the other Greek notion which gives meaning to the structure is that of hubris, the sin of pride which is always followed by divine punishment. Though 
not expressed explicitly at first, hubris is nevertheless present in the title and the foreword of Tuchman's book:

Industrial society gave man new powers and new scope while at the same time building up new pressures in prosperity and poverty, in growth of population and crowding in cities, in antagonisms of classes and groups, in separation from nature and from satisfaction in individual work. Science gave man new welfare and new horizons while it took away belief in God and certainty in a scheme of things he knew. (xii)

Therefore, time is teleological, be it in history or in fiction. The combination of industrial development, the unequal distribution of its profits and the loss of faith announce a catastrophe, a cataclysm which is the awaited retribution. MacLennan shares the same teleological conception of history as Tuchman, both inspired by Hegel's philosophy of history. His early readings of Hegel can be located in one of his very first articles published in 1936 entitled "Roman History and Today": "Any completed human pattern has a meaning; and if that meaning can be isolated and rendered coherent, it must necessarily help to explain our society to ourselves" (67). Since the only historical traces of a period take the shape of documents and monuments, it is up to the writer to fill in the gaps and give coherence to the historical structure.

MacLennan writes from within a tradition and against the logical positivism promoted by the Vienna circle that affected historical discourse at the beginning of the twentieth century. In the second half of the century, positivist academics were largely supported by the poststructuralist literary critics who, in turn, fixed the borders between fiction and history. MacLennan decided to write this essay in order to disclose his position to historians who believe that his conception of history is too dependent on fiction and critics who assert that he uses material that is proper to history or sociology: "English professors and critics in "little" magazines agreed that I introduced into my fiction material that had no business being there, material that belonged to history, even to sociology, and had no place in the aesthetics of fiction because it adulterated the symbolism" (241). In MacLennan's work, essays generally find a place in the novel by means of an omniscient narrator who transcends space and time. Historical discourse is omnipresent in all of his novels, from Barometer Rising (1941), in which the small town of Halifax in Nova Scotia becomes symptomatic of the world, to his last novel, Voices in Time (1980), a metafictional novel which puts an apocalyptic end to a world calling for historical reconstruction. To take the example of Voices in Time, comments on history pervade the novel and its structure is based on a series of framed narratives. The story is set in the year 2030 in a postapocalyptic city called Metro (built upon the ruins of Montreal), and a young architect named André Gervais finds a metal box of written, audio and video documents. They all belong to the Wellfleet family and Gervais discovers that there is only one survivor of the family: John Wellfleet. John Wellfleet, a former high school teacher, becomes the 
occasion for MacLennan to discuss how history is pieced together and written. He fills in the gaps between the documents with his personal knowledge of the period. The narrative relative to his uncle Conrad, a former university history teacher, discloses the same critique of academia. In part five, "Conrad Dehmel's story as told by John Wellfleet", the narrator focuses on the opposition between the historian's scientific and social roles:

The historians also called themselves scientists and they no more trusted the literary historians who reported the past than they trusted the newspapers that reported the present. What they wanted was hard evidence-documents, inscriptions, artefacts, the leavings in ancient tombs, chemical analyses of old coinages, papyri, lost alphabets. It was a great time for archaeology and Conrad twice joined digging expeditions in the old Middle East. The historians of this time were more interested in what had destroyed civilizations than in what had created them, apparently believing that if men could discover the mistakes of the past they could prevent politicians from repeating them in the future. (162-163)

John Wellfleet plays the role of the interpreter of these documents and he fills in the gaps with opinions that are characteristic of the essay form. The opposition between the so-called "scientific" historian in this passage and the "literary historian" is mainly based on their respective roles in society. The scientists are reproached here with keeping their knowledge to themselves and writing in a language which, according to MacLennan, is "barren of life and destitute of emotion" (240). The novel offers an artistic medium to display these comments, but the essay allows the author's personal and social involvement. At first reading, MacLennan's conception of the border between historical discourse and fiction seems similar to the postmodern preoccupation with such confusion of all discourses. In A Poetics of Postmodernism, Linda Hutcheon reminds the reader of the illusory distinction between history and literature:

What the postmodern writing of both history and literature has taught us is that both history and fiction are discourses, that both constitute systems of signification by which we make sense of the past ("exertions of the shaping, ordering imagination"). In other words, the meaning and shape are not in the events, but in the systems which make those past events into present historical facts. (Hutcheon 89)

MacLennan was well aware of the discursive nature of the historical narrative. However, his position remained firm against a postmodern trend which he thought prevented literature and history from having any social impact. His negative opinion on the self-reflexive nature of the signifier resulted from his fear that postmodernism would be detrimental to the authority of language and culture. His position against the merely aesthetic scope of the novel can only be understood by taking into account his active role as writer engagé. His commitment to society accounts for many of the essayistic interruptions in his fiction. The plots of his first novels unfold according to a given problem which needs resolution, and the 
function of the protagonists is to struggle in that direction. However, there is always a character who is secondary to the main plot to enlighten the characters or shed light on the society of their time. The omniscient narrator of the first novels gives form to interior monologues which help the reader understand the society which is inside and outside its borders. However, being engagé does not mean playing a political role, but a humanistic one. Nine years after "The Changed Functions of Fiction and Non-Fiction", MacLennan wrote another essay entitled "The Writer Engage" to make his motivations clear to the public. The essay is used here to counter the ambiguity around certain terms and he defines the socially committed writer as a person who is devoted to the enlightenment of a society and not to a political party.

His attempt consists in setting up a tribunal in which he defends a tradition of history writing meant to captivate and teach the reader, and in which he accuses the academies and the critics of alienating the public. The readers are invited to be a jury won over by his arguments. In "On the Nature and Form of the Essay", Lukács compares the essay to a tribunal, where it is not the judgement itself which is important but its process. The comparison with a tribunal is all the more pertinent in this respect as MacLennan questions authority and the legitimacy of those who desire to assert their positions as legislators. This dimension of the essay which involves research and questioning is what has contributed to the success of the genre. The essay allows the author to write from the margins, a place where personal meditations can be expressed separately from academic philosophy and history. Montaigne, still considered today to be the modern father of the genre, discusses deep philosophical concerns, but he never forgets to include his own judgement over his experience. The opening lines of Rousseau's $A$ Discourse Upon the Origin and the Foundation of the Inequality Among Mankind express his personal judgement of the human condition and his pact with his reader: "'Tis of Man I am to speak; and the very question, in answer to which I am to speak of him, sufficiently informs me that I am going to speak to men; for to those alone, who are not afraid of honouring truth, it belongs to propose discussions of this kind" (Rousseau, 1). In this respect, the essay appears as an intermediate genre which attempts to reconcile the subjective involvement of the writer in his novel and the knowledge that is too often maintained behind the walls of an institution. The essay takes all of its meaning from these questions which aim at tackling the complexity of human knowledge and how it is shared with the reader.

The approach in this essay has mainly consisted in examining the importance of the essayist's personal involvement in current debates around the scientific dimensions of history writing as well as his need to attract the reader's sympathy while contributing to the dynamism of the essay by questioning generic categories. Since very few critics over the years have paid attention to MacLennan's essays, this paper meant to explore its nature and the author's intentions. Regarding the question of the boundaries between the essay and the novel in his work, a great deal of detailed analysis remains to be done. The ascendancy of fiction in literature partly 
accounts for the rather relative position of the essay. As François Ricard explained in his article entitled "La Solitude de l'Essayiste", the essay is generally presented as second to the novel. In MacLennan's case, the essay means much more than simply criticizing a system and attempting to solve a problem. In the novel, authorial intentions are refracted, unlike the essay which offers the writer the possibility to come out in the open and share an experience with the public. His collection of essays entitled Seven Rivers of Canada (1963), each one being an aesthetic tribute to Canadian river systems, aims at arousing national awareness by bonding the readers to their landscape. In Seven Rivers of Canada, the indistinct nature of the border between history, fiction and essay is made clear. Some of his observations and comments can already be found in his second novel, Two Solitudes (1945), in which the St Lawrence plays a central part as a meeting point between the English and French communities in Quebec. More than just sharing an experience, the essay also becomes a medium for experimentation. MacLennan was also known for the action episodes of his novels. The explosion of the Mont Blanc in Halifax is central to the plot of his first published novel Barometer Rising (1941). The suspense is created by dividing and subdividing time in order to suspend it when the ship explodes. A more detailed analysis of the chronotope in MacLennan's novels can be read in a doctoral thesis that was defended at the University of la Sorbonne Nouvelle in 2008. ${ }^{2}$ The same technique is used in his essay dedicated to the national sport. In "Fury on Ice", written in 1954, MacLennan deals with the theatricality of ice hockey with its climactic moments, its outcomes and the suspense that is tangible in the audience when a penalty is about to be scored. This illustrates that MacLennan has immensely contributed to the popularity of a genre and that his influence over subsequent writers was not a minor one. In his article, "Novelist or Essayist? Hugh MacLennan and The Watch that Ends the Night", W.J. Keith agrees that his essays were crucial to the development and success of the genre: "this mingling of essay and fiction, of discursive commentary and imaginative narrative, has - in some cases, perhaps, as a result of MacLennan's influence - become a feature of modern Canadian writing" (Keith 60). The two examples of Rudy Wiebe and Robert Kroetsch are highly significant in that both are successful novelists who feel the need to connect with the reader via the essay. Rudy Wiebe wrote River of Stone in 1995 and subtitled it "Fiction and Memories". His essays scan a variety of subjects and experiences from his descriptions of small prairie towns to his approach to Inuktitut. In A Likely Story: The Writing Life, published the same year, Kroetsch writes about his personal encounters and about his questions relative to the possibility of language to clearly represent them. Along with MacLennan's essays, these writers show that the dynamic nature of the essay resides above all in its resistance to literary classification.

André DODEMAN

Université Stendhal-Grenoble 3

2. Further references provided in the bibliography. 


\section{Works Cited}

Bakhtin, Mikhail. The Dialogic Imagination. Trans. Caryl Emerson and Michael Holquist. Ed. Michael Holquist. Austin: U of Texas P, 1981.

Dodeman, André. Unpublished thesis.

Dvorak, Marta. "The English-Canadian Novel and the Displacement of the Romance", in History of Canadian Literature: English-Canadian and French-Canadian. Ed. Reingard M. Nischik. Rochester, N.Y.: Camden House, 2008. 174-193.

Frye, Northrop. Anatomy of Criticism: Four Essays. 1957. London: Penguin, 1990.

Glaudes, Pierre. Introduction. L'Essai : Métamorphoses d'un genre. Coll. Cribles. Ed. Pierre Glaudes. Toulouse: PU du Mirail, 2002. i-xxvi.

Hutt-Brichard, Marie-Catherine. "L'avant-texte de l'essai (XIX $\mathrm{XX}^{\mathrm{e}}$ siècles)." In L'Essai: Métamorphoses d'un genre. Cribles. Ed. Pierre Glaudes. Toulouse: PU du Mirail, 2002. 29-46.

Hutcheon, Linda. A Poetics of Postmodernism. New York and London: Routledge, 1988.

-. The Canadian Postmodern: A Study of Contemporary English-Canadian Fiction. New York and Oxford: Oxford UP, 1988.

Keith, W.J. "Novelist or Essayist: Hugh MacLennan and The Watch that Ends the Night." Hugh MacLennan 1982: Proceedings of the MacLennan Conference at University College. Ed. Elspeth Cameron. Toronto: University College, 1982. 55-63.

LAfon, Michel. "Essais sur l'essai." Essais sur l'essai. Les Cahiers de l'ILCEA. 4. Grenoble: Ellug, 2003. 5-13.

LukÁcs, Georg. Soul and Form. 1910. Trans. Anna Bostock. London: Merlin Press, 1974.

MacLennan, Hugh. "The Changed Functions of Fiction and Non-Fiction". The Other Side of Hugh MacLennan: Selected Essays Old and New. Ed. Elspeth Cameron. Toronto: MacMillan, 1978. 238-46.

-. "The Writer Engagé." The Other Side of Hugh MacLennan: Selected Essays Old and New. Ed. Elspeth Cameron. Toronto: MacMillan, 1978. 269-87.

—. "Roman History and Today." The Dalhousie Review. 15 (1935-36): 67-78.

-. Oxyrhynchus: An Economic and Social Study. 1935. The Hugh MacLennan Papers. Rare

Books Division. University McGill, Montreal. Container 5, file 41.

—. Voices in Time. New York: Penguin, 1980.

Ricoeur, Paul. Histoire et vérité. 1955. Paris : Seuil, coll. "Points”, 1967.

Rousseau, Jean-Jacques. A Discourse Upon the Origin and the Foundation of the Inequality Among Mankind. Ed. Greg Boroson. Mineola: Dover, 2004.

Strachey, Lytton. Eminent Victorians. London: Chatto and Windus, 1966.

Surette, Leon. "Modernism, Postmodernism, Fascism and Historicism." University of Toronto Quarterly. 60 (1990-1991): 476-492.

Tuchman, Barbara W. The Guns of August. New York: Ballantine Books, 1962.

-. The Proud Tower: A Portrait of the World before the War, 1890-1914. New York: Ballantine Books, 1966. 